\title{
ANALISIS KELAYAKAN LOKASI TEMPAT PEMROSESAN AKHIR SAMPAH AIRMADIDI BAWAH KABUPATEN MINAHASA UTARA
}

\author{
Marcell Zadke Wakkary \\ Paulus A. Pangemanan \\ Leonardus Ricky Rengkung
}

\begin{abstract}
Waste Treatment Location (TPA) in North Minahasa Regency need attention, because of the existing TPA has been ineffective so that will impact on the operational feasibility of the TPA. The current TPA is a reservoir of garbage from all over North Minahasa Regency. The management of waste in the TPA is only dredging and filling with the new waste. A new TPA becomes an urgency as a replacement for the old, because without the a new waste disposal location, may cause contamination. This study aimed to evaluate the feasibility of Waste Disposal Location (TPA) in Airmadidi Regency based on eligibility criteria of Indonesia National Standard. The benefits of this research that it can be use as a reference for the Planning and Regional Development studies in North Minahasa Regency to determent the worthiness of the existing waste Treatment location, and can be taken into consideration for regional planning regarding the worthiness of the existing waste treatment location. Research results show that in TPA Airmadidi the level of feasibility is enough or qualified in terms with minor repairs. In the aspect of social and community perceptions show that the level of eligibility Very Good, whereas in the physical aspects show that the aspects of waste management are at the feasibility level is less. It can be predicted that the capacity of Waste Treatment Location (TPA) in Airmadidi Regency until the end of 2025 is 458,121.9 metrics. This shows at the end of 2025 could still accommodate a charge of 8479.75 metrics with a high pile has reached 9.81 meter. It means that the existing TPA can still operate above 10 years but with less remaining operating time. However at the end of 2030, the existing TPA is already over load of 173,911.82 metrics with a height of pile 13.8 meter.
\end{abstract}

Key words : Waste Treatment Location, Waste Management, Land Use.

\begin{abstract}
ABSTRAK
Tempat Pemrosesan Akhir (TPA) sampah di Kabupaten Minahasa Utara perlu mendapat perhatian, dikarenakan TPA yang ada sudah tidak efektif sehingga akan mempengaruh pada kelayakan operasional TPA tersebut. TPA yang ada sekarang ini merupakan tempat penampungan sampah-sampah dari seluruh Kabupaten Minahasa Utara. Pengelolaan sampah di TPA ini hanya mengeruk dan menimbunnya dengan sampah baru. Kebutuhan TPA yang baru menjadi hal yang sangat mendesak sebagai pengganti TPA yang lama, karena tanpa adanya tempat pembuangan sampah yang baru akan menimbulkan pencemaran. Penelitian ini bertujuan untuk untuk mengevaluasi kelayakan lokasi TPA Airmadidi berdasarkan kriteria kelayakan SNI, sedangkan manfaat penelitian ini adalah dapat menjadi referensi bagi studi Perencanaan dan Pembangunan Wilayah pada Kabupaten Minahasa Utara dalam rangka menentukan kelayakan lokasi TPA sampah yang ada, dan dapat menjadi bahan kajian bagi pemerintah daerah berkenaan dengan tingkat kelayakan TPA sampah yang ada. Hasil Penelitian
\end{abstract}


menunjukkan bahwa TPA Airmadidi menunjukan tingkat kelayakan yaitu Cukup Sesuai atau memenuhi syarat dengan perbaikan ringan. Dalam aspek sosial dan persepsi masyarakat yang masing-masing berada pada tingkat kelayakan Sangat Baik, sedangkan dalam aspek fisik beradapada tingkatan cukup layak dan aspek manajemen pengelolaan sampah berada pada tingkat kelayakan kurang baik. Prediksi daya tampung TPA Airmadidi adalah $458.121,9 \mathrm{~m}^{3}$. Hal ini menunjukan pada akhir tahun 2025 masih bisa menampung muatan sebesar $8.479,75 \mathrm{~m}^{3}$ dengan tinggi timbunan sudah mencapai 9,81 m, jadi TPA masih bisa beroperasi diatas 10 tahun namun dengan sisa waktu operasi yang tidak lama lagi, sedangkan pada akhir tahun 2030, TPA sampah yang ada sudah melebihi muatan (over load) sebesar 173.911,82 $\mathrm{m}^{3}$ dengan tinggi timbunan mencapai 13,8 m.

Kata kunci: Tempat Pembuangan Akhir (TPA), Pengelolaan Sampah, Tata Guna Lahan.

\section{PENDAHULUAN}

\section{Latar Belakang}

Kabupaten Minahasa Utara terbentuk lewat Undang - Undang Nomor 33 Tanggal 18 Desember 2003 dan resmi berdiri pada tanggal 7 Januari 2004 dengan ibukota Airmadidi. Kabupaten ini memiliki lokasi yang strategis karena berada di antara dua kota, yaitu Kota Manado dan Kota Bitung, sehingga dapat dikatakan bahwa Kabupaten Minahasa Utara merupakan daerah penghubung bagi kota-kota tersebut. Pada dewasa ini, Kabupaten Minahasa Utara telah berkembang menjadi kawasan pemukiman baru dan kawasan industri. Hal ini tentunya menyebabkan pertambahan jumlah penduduk dengan cara migrasi, dimana titik konsentrasi pertambahan penduduk berada pada daerah pemukiman baru yang berlokasi di Kecamatan Kalawat, Kecamatan Airmadidi, Kecamatan Talawaan dan Kecamatan Dimembe. Pertambahan penduduk berhubungan erat dengan peningkatan jumlah sampah pada suatu daerah. Permasalahan sampah yang ada tentunya sudah menjadi masalah lingkungan yang paling serius untuk ditangani.

Sampah merupakan konsekuensi adanya aktivitas manusia dan setiap manusia pasti menghasilkan buangan atau sampah (Hidayati, 2004). Sampah adalah sisa kegiatan sehari-hari manusia dan/atau proses alam yang berbentuk padat (Undang Undang Nomor 18 Tahun 2008). Sampah juga dapat didefinisikan sebagai limbah yang bersifat padat terdiri dari zat organik dan zat anorganik yang dianggap tidak berguna lagi dan harus dikelola agar tidak membahayakan lingkungan dan melindungi investasi pembangunan (Keputusan Dirjen Cipta Karya nomor 07/KPTS/CK/1999). Adapun hal - hal negatif yang dapat diakibatkan oleh sampah adalah :

1. Secara umum, sampah bisa mempengaruhi kesehatan masyarakat sekitar karena untuk jenisjenis sampah tertentu bisa menimbulkan sumber penyakit.

2. Sampah bisa menurunkan keindahan atau nilai estetika suatu wilayah jika penanganan sampah tidak dilaksanakan secara baik.

3. Sampah bisa menyebabkan polusi udara dan untuk sampah jenis tertentu bisa menyebabkan polusi tanah dan air.

Setiap pemerintah daerah memiliki tugas melaksanakan pengelolaan sampah dan memfasilitasi penyediaan prasarana dan sarana pengelolaan sampah (Undang - Undang Nomor 18 Tahun 2008). Proses penanganan sampah yang dilakukan oleh Pemerintah Kabupaten Minahasa Utara sebagai implementasi dari peraturan tersebut adalah melakukan proses pelayanan yang dimulai proses pengumpulan sampah sampai dengan Tempat Pemrosesan Akhir (TPA) sampah dimana 
pelayanan kebersihan didasarkan pada peta geografis yang ada dan dibagi menjadi 6 (enam) zona pelayanan dimana sampah 3 (tiga) zona yaitu Kecamatan Dimembe, Kecamatan Airmadidi, Kecamatan Kalawat, Kecamatan Kauditan, Kecamatan Kema diolah di Tempat Pemrosesan Akhir (TPA) sampah yang memiliki luas area sebesar $52.290 \mathrm{~m}^{2}$ yang berlokasi di Kelurahan Airmaididi Bawah Kecamatan Airmadidi sedangkan sampah untuk 3 (tiga) zona sisa yaitu Kecamatan Talawaan, Kecamatan Likupang Barat, Kecamatan Likupang Timur, Kecamatan Likupang Selatan dan Kecamatan Wori diolah di Tempat Penampungan Sementara Terpadu. Untuk pengolahan sampah di TPA Airmadidi bawah dilaksakan proses pengomposan, pembakaran, penghalusan dan pemadatan sedangkan metode pembuangan akhir dilakukan dengan sistem Controlled Landfill yaitu dilakukan dengan cara sampah ditimbun dan dipadatkan kemudian ditutup dengan lapisan tanah yang dilakukan setiap hari pada akhir jam operasi (Badan Pengelolaan Lingkungan Hidup, 2015).

Masalah persampahan di Kabupaten Minahasa Utara pada saat ini dapat dikategorikan pada taraf mengkawatirkan, sehingga perlu penanganan serius berbagai pihak, terutama pemerintah daerah untuk membangun fasilitas Tempat Pemrosesan Akhir (TPA) Sampah yang representatif dan memadai. Gundukan sampah dalam jumlah besar maupun serakan sampah di pinggir jalan dengan mudah bisa disaksikan di sejumlah ruas jalan, baik jalan kabupaten maupun jalan nasional (Tribunmanado.co.id - Airmadidi, 2015).

Masalah sampah di Kecamatan Likupang Barat, Kecamatan Likupang Timur, dan Kecamatan Likupang Selatan juga menjadi masalah tersendiri. Warga Likupang dan Wori terus mendesak pemerintah untuk membangun Tempat Pembuangan Akhir (TPA) di Likupang dikarenakan tidak adanya TPA sampah yang melayani daerah tersebut sehingga limbah sampah milik warga sejauh ini hanya ditimbun, dibakar atau dibuang ke laut sehingga menyebabkan pencemaran lingkungan di daerah tersebut (beritamanado.com, 2015).

Pada tahun 2030, penduduk Kabupaten Minahasa Utara diprediksikan akan berjumlah 284.904 jiwa dan jumlah produksi sampah di Kabupaten Minahasa utara diprediksikan menjadi 750,664 $\mathrm{m}^{3}$ per hari dengan asumsi $2,5 \mathrm{~m}^{3}$ sampah per orang per hari dan tingkat kapasitas penduduk yang terlayani adalah sebesar $80 \%$ (Masterplan Persampahan Kabupaten Minahasa Utara, 2014). Hal ini tentunya akan menjadi pertimbangan dalam pengelolaan sampah untuk jangka panjang.

Pemerintah Kabupaten Minahasa Utara telah berkoordinasi dengan Pemerintah Provinsi Sulawesi Utara untuk mencari lokasi TPA baru untuk meningkatkan pengelolaan sampah. Dari informasi yang diperoleh, Pemerintah Provinsi telah menunjuk Konsultan Perencana untuk melakukan kajian teknis mengenai lokasi TPA sampah yang baru tersebut dan hasil menunjukkan bahwa TPA sampah yang baru akan dibangun di Desa Winuri Kecamatan Likupang Timur dengan metode Sanitary Landfill dan memiliki skala regional yaitu untuk melayani sampah dari Kabupaten Minahasa Utara, Kota Manado dan Kota Bitung. Pada tahap awal akan dilakukan pembebasan lahan sebesar 5 Ha dari 10 Ha lahan yang direncanakan. Penetapan lokasi TPA sampah yang baru telah sesuai dengan Peraturan Daerah Kabupaten Minahasa Utara Nomor 1 Tahun 2013 tentang Rencana Tata Ruang Wilayah Kabupaten Minahasa Utara Tahun 2013 2033.

Upaya yang dilakukan oleh Pemerintah untuk membangun TPA sampah yang baru adalah proyek pembangunan jangka panjang yang efeknya belum dapat dirasakan secara langsung. Karena itu, 
Pemerintah Kabupaten Minahasa Utara masih akan bergantung pada TPA sampah eksisting dalam hal pengelolaan sampah saat ini. Sehubungan dengan uraian yang tersebut diatas maka muncul keinginan untuk menganalisa kelayakan lokasi Tempat Pemrosesan Akhir Sampah di Kelurahan Airmadidi Bawah Kecamatan Airmadidi Kabupaten Minahasa Utara.

\section{Konsep Ruang dan Tata Guna Lahan}

Pengaturan penggunaan lahan secara sitematis dalam pemanfaatan sumber daya yang terbatas merupakan suatu bentuk penggunaan lahan. Penggunaan lahan pada lahan yang terbatas dapat dilakukan melalui :

1. Pengkajian kebutuhan saat ini dan masa yang akan datang, serta evaluasi kelanjutan dari lahan tersebut (land sustainability)

2. Melakukan identifikasi dan memecahkan masalah silang atau benturan kepentingan antara individu dan kepentingan umum, antara kebutuhan saat ini dan untuk generasi yang akan datang.

3. Mencari dan memilih alternatif yang sesuai dengan kebutuhan

4. Merencanakan sesuai dengan perubahan yang diinginkan

5. Penyempurnaan dan belajar dari kesalahan.

Tata guna lahan bertujuan untuk menggunakan lahan secara efisien (efficient), sama (equity) dan berkelanjutan (sustainability). Penggunaan lahan yang efisien merupakan upaya untuk menghasilkan keuntungan dengan biaya yang dikeluarkan rendah, sehingga dapat dikatakan dalam hal ini terdapat unsur ekonomi. Selanjutnya penggunaan lahan harus diperlakukan sama terhadap semua orang, sehingga dapat menghilangkan kesenjangan sosial di kalangan masyarakat. Disamping itu tata guna lahan harus dapat memadukan antara kebutuhan yang dihadapi pada saat ini dan kebutuhan bagi generasi yang akan datang.

Penilaian dan pengelompokan lahan menurut kesesuaian lahannya (landsuitability) merupakan suatu bentuk kesesuaian relatif lahan dan kesesuaian absolut lahan bagi suatu penggunaan tertentu. Kesesuaian lahan berbeda artinya dengan kemampuan lahan. Kemampuan lahan lebih ditekankan pada perhatian terhadap potensi atau kapasitas lahan itu sendiri untuk suatu penggunaan tertentu, sedangkan kesesuaian dipandang sebagai kenyataan adaptasi sebidang lahan untuk suatu macam penggunaan tertentu. Ruang merupakan hal yang sangat penting di dalam pembangunan.

Menurut Budiharsono (2001) "Konsep ruang terdiri atas beberapa unsur, yaitu: (1) jarak; (2) lokasi; (3) bentuk dan (4) ukuran". Konsep ruang sangat berkaitan dengan waktu, karena dalam hal pemanfaatan bumi dan kekayaannya membutuhkan organisasi atau pengaturan ruang dan waktu. Unsurunsur tersebut di atas secara bersama-sama menyusun unit tata ruang.

\section{Pengertian Sampah}

Sampah adalah limbah yang bersifat padat terdiri dari bahan organik dan bahan anorganik yang dianggap tidak berguna lagi dan harus dikelola agar tidak membahayakan lingkungan dan melindungi investasi pembangunan (Standar Nasional Indonesia No. 19-3964-1994 tahun 1994). Keberadaan sampah tidak diinginkan bila dihubungkan dengan faktor kebersihan, kesehatan, kenyamanan dan keindahan, sehingga harus dikelola agar tidak membahayakan lingkungan yang mengakibatkan kemunduran lingkungan (urban environment degradation) dan dapat membahayakan kehidupan manusia (Tchobanoglous, 1997). Menurut Kodoatie (2003) sampah adalah segala buangan akibat aktifitas manusia dan hewan, biasanya berupa padatan yangdianggap tidak berguna lagi. 
Menurut Azwar (1990), sampah dalam ilmu kesehatan lingkungan (refuse) sebenarnya hanya sebagian dari benda atau hal-hal yang dipandang tidak digunakan, tidak dipakai, tidak disenangi atau harus dibuang. Sampah yang dibuang akan menjadi beban bumi, yang artinya ada resiko-resiko yang akan ditimbulkannya (Hadi, 2000). Dengan kata lain sampah adalah sisa-sisa bahan yang mengalami perlakuan-perlakuan, baik karena telah diambil bagian utamanya atau karena pengolahan dan sudah tidak ada manfaatnya bila ditinjau dari segi sosial ekonomis tidak ada harganya, sedangkan dari segi lingkungan dapat menyebabkan pencemaran atau gangguan lingkungan.

\section{Sumber dan Produksi Sampah}

Sumber sampah berasal dari berbagai fasilitas dan aktifitas manusia yangdapat dihubungkan dengan tata guna lahan dan peruntukkannya. Melalui pemahaman sumber sampah dapat diketahui timbulan sampah yang dihasilkan. Jumlah timbulan sampah perlu diketahui untuk menentukan jumlah sampah yangakan dikelola, hal ini erat kaitannya dengan sistem pengumpulan dan pembuangan akhir sampah yang menyangkut jenis sarana dan jumlah peralatan yang dibutuhkan. Jenis sampah yang dihasilkan menurut sumber akan berbeda antara satu sumber dengan sumber lainnya.

Menurut Standard Nasional Indonesia No. 19-39641994 sampah berasal dari:

1. Sumber sampah perumahan yaitu: rumah permanen, rumah semi permanen, dan rumah non permanen.

2. Sumber sampah non permanen yaitu: kontor, toko/ruko, pasar, sekolah, jalan, hotel, restoran, dan fasilitas umum lainnya.

Menurut Standar Nasional Indonesia Nomor T-131990-F yang dikeluarkan oleh Departemen Pekerjaan Umum pengertian timbulan sampah atau produksi sampah adalah banyaknya sampah yang dihasilkan suatu wilayah per hari, dinyatakan dalam satuan volume ataupun dalam satuan berat. Guna memperoleh timbulan sampah, perlu ditinjau sumber-sumber penghasil sampah yang ada. Lokasi yang menjadi sumber timbulan sampah antara lain :

1. Sampah domestik, yaitu sampah yang dihasilkan oleh aktivitas manusia secara langsung seperti sampah rumah tangga, sekolah, dan pusat keramaian

2. Sampah non domestik, yaitu sampah yang dihasilkan oleh aktivitas manusia secara tidak langsung, seperti : sampah industri, pertanian, peternakan, kehutanan, dan transportasi.

Pengelolaan sampah di Indonesia diatur melalui peraturan daerah dengan tujuan memindahkan sampah dari tempat asalnya ke tempat penampungan akhir dengan cepat agar tidak membahayakan lingkungan. Secara umum pengelolaan sampah di perkotaan menurut Standar Nasional Indonesia Nomor T-13-1990-F yang dikeluarkan Departemen Pekerjaan Umum dilakukan melalui 3 tahapan kegiatan, yakni Pengumpulan sampah dilakukan mulai dari tempat asalnya, seperti rumah-rumah, kantor-kantor dan sumber penghasil sampah lainnya. Untuk kawasan permukiman penanganan sampah dilakukan oleh organisasi RT/RW. Pengumpulan dilakukan menggunakan gerobak sampah dari rumah ke rumah, kemudian sampah ditampung di tempat penampungan sampah sementara (TPS). pTPS tersebar diseluruh wilayah kota yang didasarkan pada area yang akan dilayani. Area pelayanan kawasan komersial seperti pertokoan, perkantoran danpermikiman tertentu, sampah diambil langsung oleh truk yang berkelilingkemudian menuju TPA.

Sampah yang terkumpul di TPS kemudian diangkut dengan truk khusus. Sebagian sampah diangkut menuju tempat untuk mendapat penanganan lebih lanjut misalnya, incenerator atau pengomposan (bila proses ini ada) dan sisanya menuju ke TPA. 
Sampah yang tidak dimanfaatkan lagi diangkut menuju penampungan akhir (TPA). Sampah ditimbun menurut tata cara pengelolaan sampah di TPA.

Kegiatan-kegiatan tersebut merupakan suatu sistem, sehingga masing-masing tahapan dapat disebut sebagai sub sistem. Kegiatan pewadahan sampai dengan pembuangan akhir sampah harus bersifat terpadu dengan melakukan pemilahan sejak di sumbernya. Untuk menempatkan sampah sebagai produk masyarakat akibat dari aktifitas kehidupan dan sudah tidak dimanfaatkan lagi, dibutuhkan ruang.

Parameter yang mempengaruhi sistem pengelolaan sampah perkotaan adalah sebagai berikut :

a) Kepadatan dan penyebaran penduduk.

b) Karakteristik fisik lingkungan dan sosial ekonomi.

c) Timbulan dan karakteristik sampah.

d) Budaya, sikap dan perilaku masyarakat.

e) Jarak dari sumber sampah ke Tempat Pemrosesan Akhir sampah (TPA).

f) Rencana tata ruang dan pengembangan kota.

g) Sarana pengumpulan, pengangkutan, pengolahan dan pembuangan akhir sampah.

h) Biaya yang tersedia.

i) Peraturan Daerah setempat yang terkait.

j) Sumber Daya Manusia yang tersedia.

Beberapa pendekatan teknologi pengelolaan sampah, dikemukakan oleh Tusy (1999), yaitu:

1. Penanganan sampah terintegrasi (integrated solid wste management), dilakukan melalui hirarki pengelolaan sebagai berikut:

a. Pengurangan sampah pada sumbernya (source reduction). Tahap inimeliputi pengurangan jumlah atau toksisitas sampah, hal ini sangat efektif dalam mengurangi kuantitas sampah, biaya penanganan, serta dampak terhadap lingkungan yang dilakukan melalui perancangan dan fabrikasi bahan pengemas produk dengan kandungan toksisitas yang rendah, volume bahan yang minimum serta tahan lama.

b. Daur ulang sampah melalui pemisahan dan pengelompokan sampah; persiapan sampah untuk diguna ulang, diproses ulang, dan difabrikasi ulang; penggunaan, pemrosesan dan fabrikasi sampah.

c. Transformasi limbah dalam upaya merubah bentuk sampah melalui proses fisika, kimia maupun biologi. Keuntungan tahap ini antara lain meningkatnya efisiensi sistem dan operasi pengelolaan sampah; diperolehnya bahan yang dapat diguna ulang (re-use) dan di daur ulang(recycling); dan diperolehnya produk hasil konversi (seperti kompos) dan energi dalam bentuk panas dan biogas.

d. Landfilling, cara ini merupakan alternatif terakhir dan dilakukan terhadap sampah yang tidak dapat didaur ulang dan tidak dapat dimanfaatkan lagi.

2. Teknologi proses dan pemisahan sampah, teknologi ini digunakan untuk pemisahan pemrosesan bahan sampah.

3. Teknologi konversi secara thermal, teknologi ini digunakan untuk mengurangi volume sampah sekaligus untuk mendapatkan energi yang dapat dikelompokan menjadi proses pembakaran (combustion), gasifikasi (gasification) dan pirolisa (pyrolisis).

4. Teknologi konversi secara biologis, teknologi ini digunakan untuk memanfaatkan sampah melalui proses biologis yang dapat menghasilkan kompos, energi (gas methan) atau gabungan keduanya.

5. Teknologi konversi secara kimiawi, cara ini digunakan untuk memproses sampah dengan menghasilkan produk kimia seperti glukosa, furtural,minyak, gas sintetis, selulosa asetat. 
6. Landfilling, merupakan usaha terakhir setelah dilakukan proses-proses sebelumnya.

\section{Rumusan Masalah}

Permasalahan sampah di Kabupaten Minahasa Utara perlu mendapatkan perhatian, dikarenakan beberapa wacana yang timbul seperti gundukan sampah dalam jumlah besar, serakan sampah di pinggir jalan maupun pencemaran lingkungan. Solusi dari pemerintah berupa pembangunan TPA Sampah yang baru merupakan solusi jangka panjang yang belum dapat dirasakan manfaatnya secara langsung, sehingga TPA sampah eksisting masih tetap akan digunakan sampai dengan beberapa tahun ke depan. Hal ini menimbulkan beberapa pertanyaan untuk dilakukan analisis lebih mendalam yaitu :

1. Bagaimana tingkat kelayakan dari TPA sampah yang berlokasi di Kelurahan Airmadidi Bawah Kecamatan Airmadidi?

2. Berapa kapasitas daya tampung dari TPA sampah yang berlokasi di Kelurahan Airmadidi Bawah Kecamatan Airmadidi sampai dengan 10 (sepuluh) hingga 15 (lima belas) tahun kedepan?

\section{Tujuan Penelitian}

Tujuan penelitian ini terdiri dari dua hal yaitu :

1. Menganalisis tingkat kelayakan dari TPA sampah yang berlokasi di Kelurahan Airmadidi Bawah Kecamatan Airmadidi

2. Menganalisis kapasitas daya tampung dari TPA sampah yang berlokasi di Kelurahan Airmadidi Bawah Kecamatan Airmadidi sampai dengan 10 (sepuluh) hingga 15 (lima belas) tahun kedepan

\section{Manfaat Penelitian}

Manfaat yang diharapkan dalam penelitian yang akan dilakukan adalah:

1. Menjadi bahan referensi bagi studi Perencanaan dan Pembangunan Wilayah, terutama dalam hal tingkat kelayakan lokasi dan daya tampung TPA sampah.

2. Dapat dijadikan sebagai bahan kajian bagi pemerintah daerah khususnya berkenaan dengan tingkat kelayakan lokasi dan daya tampung TPA sampah.

\section{METODE PENELITIAN}

\section{Waktu dan Tempat Penelitian}

Penelitian ini dilakukan di TPA Airmadidi Bawah, Kecamatan Airmadidi, Minahasa Utara pada bulan Februari sampai dengan bulan April 2015

\section{Metode Pengumpulan Data}

Data yang digunakan dalam penelitian ini berupa data primer dan data sekunder. Teknik pengumpulan data dalam penelitian ini adalah sebagai berikut:

- Observasi Lapangan

Observasi dilakukan di lokasi penelitian yaitu di TPA Airmadidi Kabupaten Minahasa Utara.

Data yang dikumpulkan dengan metode ini antara lain jumlah sampah yang masuk ke TPA Airmadidi, teknik pengelolaan TPA serta kondisi fisik TPA Airmadidi.

- Wawancara

Wawancara menggunakan daftar pertanyaan atau kuesioner. Data-data yang dikumpulkan dengan metode pengumpulan data ini antara lain penerimaan masyarakt, kondisi lingkungan, kondisi sosial masyarakat terkait dengan 
dampak yang dimungkinkan timbul dari kondisi eksisting TPA Airmadidi.

\section{Metode Pengambilan Sampel}

Dalam penelitian ini diperlukan pengambilan data melalui metode survei. Data primer yang akan diperoleh dengan menggunakan teknik kuesioner, data ini berkaitan dengan data persepsi masyarakat dalam penetapan lokasi TPA sampah Airmadidi Bawah. Sebelum dilakukan survei perlu ditentukan terlebih dahulu sampel dari populasi yang akan diambil.

Guna menentukan populasi yang akan diambil dalam penelitian ini menggunakan metode sampel acak sederhana (simple random sampling).

\section{Metode Analisis Data}

Analisis data yang digunakan dalam penelitian ini adalah Analisis Kuantitatif dan Analisis Kualitatif. Analisis kuantitatif adalah analisis yang mempergunakan alat analisis berupa model-model, seperti model matematika, model statistik dan model ekonometrik yang hasil analisisnya berbentuk angka-angka dan selanjutnya akan diuraikan atau didiskripsikan. Disamping digunakan analisis kapasitas daya tampung TPA, Analisis Kelayakan Lokasi TPA Sampah (Metode Scorring)

\section{HASIL DAN PEMBAHASAN}

\section{Identitas Responden}

Identitas responden yang ditanyakan terdiri atas umur responden, jenis kelamin, pekerjaan, pendidikan, status kependudukan, lama bertempat tinggal, status responden dalam keluarga, status rumah dan jumlah anggota keluarga dan masing-masing jawaban yang disampaikan adalah sebagai berikut:

1) Umur Responden

Pada umumnya responden berumur antara 41 sampai dengan 50 tahun (22\%), yang diikuti oleh mereka yang berumur antara 51 tahun sampai dengan 60 tahun (21\%) dan yang berumur antara 21 tahun sampai dengan 30 tahun (18\%). Paling sedikit responden yang mengemukakan adalah berumur $<20$ tahun $(15 \%)$.

2) Jenis Kelamin

Perbandingan jenis kelamin antara laki-laki dan perempuan hampir seimbang, yaitu laki-laki (58\%) dan perempuan (42\%).

3) Pekerjaan/Mata Pencaharian

Mata pencaharian responden di kawasan lokasi TPA pada umumnya bekerja pada instansi swasta sebesar 44\%. Kemudian pekerjaan responden masing-masing sebesar 22\% adalah ibu rumah tangga, diikuti Lainnya sebesar 14\%, $10 \%$ berikutnya adalah pelajar atau mahasiswa, 7\% merupakan buruh atau tani, dan responden yang paling sedikit adalah dari PNS/TNI/Polri sebesar 3\%.

4) Tingkat Pendidikan

Tingkat pendidikan responden sebagian besar adalah tamat SMA (64\%), yang diikiuti dengan yang berpendidikan tamat SMP (19\%) dan yang berpendidikan tamat SD $(11 \%)$. Tingkat pendidikan lainnya adalah Sarjana (3\%).

5) Status Kependudukan

Responden penduduk asli dimana kelahiran setempat sebanyak $88 \%$ dan pendatang sebanyak $12 \%$.

6) Lama Bertempat Tinggal

Pada umumnya para responden sudah bertempat tinggal di rumahnya yang saat ini lebih dari 15 tahun (79\%), responden bertempat tinggal kurang dari 5 tahun (11\%) diikuti oleh responden yang bertempat tinggal 5 sampai 10 tahun sebesar 7\%. Dan responden 
yang bertempat tinggal lebih dari 15 tahun sebesar 3\%

7) Status Rumah

Status rumah responden pada umumnya adalah rumah sendiri (64\%). Status rumah orang tua (31\%), rumah kontrak/sewa sebesar $2 \%$.

\section{Persepsi Masyarakat Terhadap Lokasi TPA}

Persepsi masyarakat diketahui dengan mengajukan pertanyaan-pertanyaan yang terkait dengan sudut pandang responden terhadap TPA. Parameter yang ditanyakan terkait Persepsi responden antara lain mengenai manfaat TPA.

\section{Analisis Kelayakan Lokasi TPA sampah}

\section{Aspek Fisik}

Aspek Fisik mempengaruhi daya dukung lahan terhadap suatu kegiatan/aktivitas. Penggunaan lahan yang tidak sesuai daya dukung lahan dapat menimbulkan terjadinya kerusakan lingkungan dan akan meningkatkan masalah sosial. Aspek fisik wilayah yang berpengaruh terhadap kelayakan lokasi TPA antara lain curah hujan, kelerangan, muka air tanah dan litologi.

Wilayah Minahasa Utara ditinjau dari curah hujan, masuk pada kelas kelayakan S-3 (sangat layak), dimana angka rata-rata curah hujan setiap tahun berkisar 2.000-3.000 mm dengan jumlah hari hujan 90-130 hari/tahun . Besarnya curah hujan berkaitan dengan limpasan air permukaan yang tinggi sehingga sampah aka menjadi mudah runtuh dan pengelola juga akan kesulitan dalam penyediaan TPA. Dengan kondisi curah hujan yang termasuk sedang, maka tidak ada hambatan dari segi curah hujan.

Ditinjau dari dasar elevasi atau ketinggian garis kontur, wilayah Airmadidi yang menjadi lokasi TPA masuk dalam kelas kelayakan S-1 (sangat layak, memenuhi syarat tanpa hambatan) dengan kelerang tanah rata-rata $<2 \%$ dan ketinggian berada pada $24 \mathrm{~m}$ diatas permukaan laut. Kemiringan lereng berkaitan erat dengan kemudahan pekerjaan konstruksi dan operasional TPA sampah. Semakin terjal suatu daerah semakin sulit pekerjaan konstruksi dan pengoperasiannya (Alfiani, 2012). Wilayah Minahasa Utara termasuk sesuai dengan kelas kelerangan untuk lokasi TPA, karena wilayahnya relatif datar.

Jenis batuan berperan penting dalam mencegah atau mengurangi penemaran air tanah dan permukaan secara alami yang berasal dari air lindi. Jenis batuan di wilayah airmadidi masuk dalam kelas kelayakan S-3 (Kurang Layak) dimana jenis batuan yang ada berupa Batu Pasir, Bresi Sed., breksi volk. Tersier, Breksi Volk. Kuarter, Batuan beku, dan Alluvial.

\section{Aspek Sosial}

Aspek sosial diukur berdasarkan SK SNI No 193241-1994 dan disesuaikan dengan kondisi yang ada di lokasi TPA. Hasil dari penilaian kelayakan sosial menunjukan TPA Airmadidi masuk dalam kelas kelayakan S-1 dengan kriteria sangat layak (memenuhi syarat tanpa hambatan).

\section{Aspek Persepsi Masyarakat}

Aspek Persepsi masyarakat diketahui dengan menyebarkan kuisioner kepada 100 (serarus) orang responden yang berdomisili di sekitar wilayah TPA.

\section{Kelayakan TPA}

Hasil penelitian meunjukan TPA Airmadidi memiliki nilai kelayakan manajemen Kurang Baik (memenuhi syarat dengan perbaikan agak berat) dengan poin 43 pada kelas kelayakan S-3. Ini dikarenakan belum sesuainya kondisi lapangan dengan desain tapak TPA, kemudian belum efektifnya kegiatan pengomposan sampah basah yang dikelola, serta belum adanya ketersediaan kolam leachet pada TPA. Sistem pengelolaan di lokasi TPA masih menggunakan sistem open dumping. Sebenarnya sistem ini tidak boleh lagi 
digunakan sejak keluarnya Undang-Undang Nomor 18 Tahun 2008, hanya masih banyak pengelola TPA yang belum siap untuk menggunakan sistem yang lain. Oleh karena itu diperlukan perbaikanperbaikan agar manajemen pengelolaan TPA dapat berjalan dengan baik.

Hasil dari penelitian terhadap tingkat kelayakan TPA menunjukan, TPA Airmadidi memiliki nilai total 268, berada pada tingkat kelayakan S-2 yaitu Cukup Sesuai (Memenuhi syarat dengan perbaikan ringan). TPA Airmadidi memiliki nilai yang baik pada aspek sosial dan Persepsi masyarakat, cukup baik pada aspek fisik dan kurang pada aspek manajemen. Oleh karena itu TPA Airmadidi ini harus dapat meningkatkan lagi perfomanya dalam aspek manajemen pengelolaan sampah di TPA agar dapat berfungsi secara maksimal.

\section{Kapasitas Daya Tampung TPA}

Dalam memprediksi daya tampung TPA Airmadidi maka data yang diperlukan adalah data volume sampah yang ada, prediksi peningkatan jumlah penduduk, luas lahan TPA, rencana umur TPA, dan rencana tinggi timbunan.

\section{KESIMPULAN}

Berdasarkan analisis terhadap kelayakan TPA di wilayah penelitian menunjukan tingkat kelayakan TPA Airmadidi memiliki nilai total 268, berada pada tingkat kelayakan S-2 yaitu Cukup Sesuai (Memenuhi syarat dengan perbaikan ringan).

TPA Airmadidi memiliki nilai yang baik pada aspek sosial dan Persepsi masyarakat yang masingmasing berada pada tingkat kelayakan S-1 (Sangat Baik), sedangkan aspek fisik beradapada tingkatan S-2 (cukup layak) dan aspek manajemen pengelolaan sampah berada pada tingkat kelayakan S-3 (kurang baik).

Prediksi daya tampung TPA Airmadidi sampai akhir tahun 2025 adalah 458.121,9 $\mathrm{m}^{3}$. Hal ini menunjukan pada akhir tahun 2025 masih bisa menampung muatan sebesar $8.479,75 \mathrm{~m}^{3}$ dengan tinggi timbunan sudah mencapai 9,81 m. Jadi TPA masih bisa beroperasi diatas 10 tahun namun dengan sisa waktu operasi yang tidak lama lagi.

Prediksi daya tampung TPA Airmadidi sampai akhir tahun 2030 adalah 458.121,9 $\mathrm{m}^{3}$. Hal ini menunjukan pada akhir tahun 2030 sudah melebihi muatan (over load) sebesar 173.911,82 $\mathrm{m}^{3}$ dengan tinggi timbunan mencapai $13,8 \mathrm{~m}$.

\section{SARAN}

Hasil penelitian telah menunjukan bahwa TPA Airmadidi cukup sesuai dan memenuhi syarat untuk dijadikan sebagai TPA tapi dengan sedikit perbaikan. Salah satu aspek yang harus diperbaiki adalah manajemen pengelolaan sampah yang belum maksimal. Kiranya instansi-instansi terkait dapat memperhatikan kekurangan-kekurangan yang ada agar dapat diperbaiki sehingga TPA Airmadidi ini dapat memaksimalkan aktifitas operasionalnya.

\section{DAFTAR PUSTAKA}

Anonim, 2012. Buku Putih Sanitasi Kabupaten Minahasa Utara. , http://klabatnewsok.com/?page_id=1641c

diakses tanggal 11 November 2015 jam 13.13

, beritamanado.com diakses Agustus 2015.

BPS Kabupaten Minahasa Utara. 2015. Kecamatan Airmadidi Dalam Angka. Badan Pusat Statistik Kabupaten Minahasa Utara.

BPS Kabupaten Minahasa Utara. 2015. Minahasa Utara Dalam Angka. Badan Pusat Statistik Kabupaten Minahasa Utara. 
Alfiani, Dena. 2012. Karakateristik Lokal sebagai Studi Tentang Keberlanjutan Tempat Pemrosesan Akhir Sampah di Daerah Perkotaan. Tesis: Program Pasca Sarjana, Magister Ilmu Geografi Fakultas Matematika dan Ilmu Pengetahuan Alam Universitas Indonesia, Jakarta

Anggraini , O.D dan Rahardyan, B. 2010. Pemilihan Lokasi TPA dengan Metode GIS DI Kabupaten Bandung Barat. Program Studi Teknik Lingkungan, Fakultas Teknik Sipil dan Lingkungan ITB. Bandung.

Azwar, Azrul, 1990, "Pengantar Ilmu Lingkungan", Mutiara Sumber Widya, Jakarta

Basyarat, Ade. 2006. Kajian Terhadap Penetapan Lokasi TPA Sampah Leuwinanggung-Kota Depok. Tesis: Program Pasca Sarjana, Magister Teknik Pembangunan Wilayah dan Kota Universitas Diponegoro, Semarang.

BSN. 1994. SNI Nomor 03-3241-1994, Tata Cara Penentuan TPA. Badan Standarisasi Nasional. Jakarta

BSN. 1998. Tata Cara Perencanaa TPA Sampah. Badan Standarisasi Nasional. Jakarta

Budhiharsono, Sugeng, 2001, Teknik Analisis Pembangunan Wilayah Pesisir dan Lautan, Pradnya Paranita, Jakarta

Departemen Pekerjaan Umum. 1990. SK SNI T-131990-F, Tata Cara Pengelolaan Teknik Sampah Perkotaan. DPU. Jakarta

Departemen Pekerjaan Umum. 1991. SK SNI T-111991-03, Persyaratan TPA. DPU. Jakarta

Dinas Tata Ruang Kabupaten Minahasa Utara. Laporan Rencana Tata Ruang Wilayah (RTRW) Kabupaten Minahasa Utara 2013. Dinas Tata Ruang Kabupaten Minahasa Utara.
Hadi P Sudharto. 2001. Dimensi Lingkungan Perencanaan Pembangunan. Gadjah Mada University Press, Yogyakarta

Hendrawan, R. 2004. Analisa Transportasi Sampah Perkotaan Studi Kasus Kota Denpasar (Tugas Akhir). Universitas Udayana. Denpasar.

Hidayati, N., (2004), Mengelola Sampah, Mengelola Gaya Hidup http://www.walhi.or.id tanggal 11 November 2015 jam 14.25

Khadiyanto, Parfi, 2005, Tata Ruang Berbasis pada Kesesuaian Lahan, Universitas Diponegoro, Semarang.

Kodiatie, Robert J, 2003, "Manajemen dan Rekayasa Infrastruktur", Pustaka Pelajar, Yogyakarta.

Nazir, Moh, 2003, Metode Penelitian, Ghalia Indonesia, Jakarta.

Oktariadi, Oki, 2010. Penentuan Zona Kelayakan TPA Sampah Berdasarkan Aspek Geologi Lingkungan DI Wilayah Provinsi Banten. Makalah Sosialisasi Geologi Lingkungan Untuk Penataan Ruang Provinsi Banten, 24 Juni 2010. Cilegon.

Pengelolaan Limbah dan Pemulihan Kerusakan Lingkungan, BPPT, Jakarta, 13 Juli 1999.

Panudju, Bambang, 199 engadaan Perumahan Kota dengan Peran Serta Masyarakat Berpenghasilan Rendah, Alumni, Bandung

Riduwan, 2002, Skala Pengukuran Variabelvariabel Penelitian, Penerbit Alfabeta, Bandung.

Sulistyorini, Lilis. 2005. Pengelolaan Sampah Dengan Cara Menjadikannya Kompos. Jurnal Kesehatan Lingkungan, Vol. 2, No. 1, Juli $2005: 77$ - 84

Tchobanoglous, G., Teisen H., Eliasen, R, 1977, Integrated Solid Waste Manajement, Mc. Graw Hill: Kogakusha, LTd 
Tjahjati B, 1996. Visi Pengelolaan Perkotaan Dalam Menghadapi Tantangan Pembangunan Perkotaan Pada Pembangunan Jangka Panjang Tahap Kedua. Makalah disampaikan pada Seminar Manajemen Perkotaan Masa Depan, Forum Manajemen Perkotaan, Bandung, 17 Januari1996.

Tusy, 1999. Teknologi Pengelolaan Limbah dan Pemulihan Kerusakan Lingkungan. Makalah disampaikan pada Seminar Teknologi
Wibowo, Irawan. 2011. Prediksi Kebutuhan Daya Tampung Tempat Pemrosesan Akhir Sukosari Jumantono Karanganyar Pada Tahun 2016. Tugas Akhir: Program DIII Infrastruktur Perkotaan Jurusan Teknik Sipil Fakultas Teknik Universitas Sebelas Maret Surakarta. 